\title{
Low Level of Genetic Variation and Signs of Isolation in the Native Hungarian Sea Buckthorn Population Compared to Cultivated Specimens
}

\author{
Maria HÖHN ${ }^{1 * a}$, Magdolna SZELÉNYI ${ }^{2 b}$, Júlia HALÁSZ3 \\ ${ }^{1}$ Szent István University, Faculty of Horticultural Science, Department of Botany, H-1118 Budapest, 44 Ménesi street, \\ Hungary; hohn.maria@kertk.szie.hu ( ${ }^{*}$ correspondingauthor) \\ ${ }^{2}$ Plant Protection Institute, Department of Zoology, Centre for Agricultural Research, HAS Herman Ottó street 15, 1022 Budapest, Hungary; \\ szelenyi.magdolna@agrar.mta.hu \\ ${ }^{3}$ Szent István University, Faculty of Horticultural Science, Department of Genetics and Plant Breeding, H-1118 Budapest, 44 Ménesi street, \\ Hungary; halasz.julia@kertk.szie.hu \\ ${ }^{a, b}$ These authors contributed equally to this work
}

\begin{abstract}
Sea Buckthorn population from Újpest Nature Reserve, the only one assumed to be native in Hungary sustains at the periphery of Budapest city on the sandy substrate deposited by the Danube river. The study aims to characterize the gene stock preserved on this small edaphic habitat by comparing with the genetic material of planted specimens of known origin used in horticultural and gardening practice. Fragment length variations of seven nuclear microsatellite markers were evaluated and a phylogenetic tree was constructed based on sequence variation of an intron from nuclear gene encoding the chalcone synthase enzyme. Gender rate was evaluated by female specific SCAR marker. Microsatellite analysis pointed out the extremely low variation of the natural sea buckthorn population from Újpest Nature Reserve compared to the cultivated specimens, while the phylogenetic tree revealed that the natural population belongs to the genetic lineage distributed mostly in Western and Middle-Europe, and in Romania, region, which has strong links to the Balkan and the Black Sea. The analysis clearly separated the genetic material of the native Újpest population from the planted individuals from the vicinity that proved to be of allochthonous origin. The HrX2 SCAR marker revealed the dominance of the males (1:1.42). The study provides support for the autochthonous origin of the Hungarian remnant population being in reproductive isolation that suggest for its long persistence and relict status. Ex situ conservation and nature protection measures are highly recommended to maintain one of the last native sea buckthorn populations of the Pannonian region.
\end{abstract}

Keywords: chalcone synthase intron; gender rate; gene reserve; Hippophae rhamnoides; phylogenetic tree; SCAR marker; SSR diversity

\section{Introduction}

The genus Hippophae - belonging to the Eleagnaceae family, commonly known as sea buckthorn comprises seven species: $H$. rhamnoides, $H$. goniocarpa, $H$. neurocarpa, $H$. litangensis, $H$. gyantsensis, H. salicifolia and $H$. tibetana (Sun et al., 2002). The area of the buckthorn species covers the Quinghai-Tibetan plateau and adjacent areas, except $H$. rhamnoides, which is widely distributed both in Asia and Europe (Bartish et al., 2000, 2002; Jia et al., 2012). H. rhamnoides comprises eight subspecies (Swenson and Bartish, 2003). According to Rousi (1965) the Hungarian provenances belong to subspecies carpatica. However, in Hungary, the only population assumed to be native grows at the northern border of Budapest city, on the sandy substrate deposited by the Danube River. The protected area called sea buckthorn Nature Reserve of Újpest (Gadó and Kerényi-Nagy, 2012), was established in 1999 with the primary scope of preserving the last remnants of the native Hungarian sea buckthorn gene stock. This pioneer shrub has a great importance in sustaining also the local ecosystem of the open sandy grassland characterized by a series of perennial species specific for the Pannonian lowland area. The sand dunes of low nutrient content provide long-term survival for this pioneer species as well for other sandy species of high adaptive potential and low competitive ability. However, large parts of the sandy vegetation along the Danube have been destroyed because of the expansion of the city. Nature protection activities are of high importance to hinder ongoing secondary succession that 
700

may cause final decline of this specific remnant habitat preserving rare species like the sea buckthorn.

H. rhamnoides is a deciduous, dioecious, frost-resistant shrub with genetically determined diploid cytotype $(2 n=$ 24) (Rousi, 1965). The flowers are wind-pollinated, the fruits are fleshy pseudodrupes (Mangla et al., 2015). Its common name comes from its habitat: sea buckthorn grows on dunes along the Black, North and Baltic Seas, or along the river banks, valley slopes, mountain streams of low or middle altitudes (Lian et al. 1998). It has a clonal structure spreading mainly by root suckers, and in this way can fast colonize the adjacent areas (Bartish et al., 2000). Generative propagation of buckthorn is implemented by bird-dispersed seeds. The average lifetime of a plant was reported to be 3040 years; older than 80 years old genotypes were not described (Gadó and Kerényi-Nagy, 2012). As early successional species with fragmented and isolated distribution it is presumed to show genetic pauperisation, and signs of genetic drift (Bartish et al., 1999).

Sea buckthorn is an economically and ecologically important multi-purpose plant. Its health protective effect was known already since 5000 BC (Kalia et al., 2011). Different extracts of leaf showed antiviral and anticancer activity (Enkhtaivan et al., 2017). However the sea buckthorn oil is known to have one of the most important pharmacological effects. The fruits of $H$. rhamnoides are rich in carotenoids, lipids, ascorbic acid, tocopherols, sterols, flavonoids and triterpenes. Due to several health-protecting compounds, sea buckthorn has been extensively used in food and cosmetic industry (Bawa et al., 2002). The plant has also other popular qualities like nitrogen fixation capacity, soil improvement and ornamental value (Sezen et al., 2015). The wide range of infraspecific morphological diversity can serve as a good potential for plant improvement by crossbreeding or selection. Because of its high use individuals were planted by people from the early times. Breeding programs were established in several European countries with main purposes: high yield, bigger fruit size, thornless, better fruit quality and growth habit. Until now, many valuable cultivars are available ( $\mathrm{Li}$ and Schroeder, 1996). Sea buckthorn has been widely planted also as protective buffer strips along the main roads.

Molecular markers are excellent tools for selecting genetic traits at an early stage and for assessing genetic potential or for screening genetic diversity due to their high polymorphism and ability to reveal a high number of alleles for each locus, resulting in a high degree of variability and reproducibility (Kalia et al., 2011). During the last decade, the popularity of Hippophae species has attracted considerable attention from researchers and several molecular analyses were carried out. RAPD markers (Sheng et al., 2006; Lacis and Kota-Dombrovska, 2014), ISSR markers (Tian et al., 2004, Li et al., 2009), AFLP (Raina et al., 2012) or combined methods (Srihari et al., 2013) were applied to assess genetic diversity. For gene tagging, genotyping and molecular breeding, two sets of SSR markers were developed: Wang et al. (2008) published 9 microsatellite markers developed for subsp. sinensis, while Jain et al. (2010) introduced 11 EST-based SSR markers for $H$. salicifolia and $H$.rhamnoides.
Sex-linked markers for Hippophae are also available to identify the gender, as sex of the seedlings cannot be determined until the shrubs do not start flowering. Korekar et al. (2012) developed two, female specific SCAR-markers on subsp. turkestanica. The $\mathrm{HrXl}$ was successfully used by Chawla et al. (2014) on $H$. salicifolia and $H$. tibetana. To investigate the intraspecific phylogeny, phylogeographic structure, expansion and demographic history of sea buckthorn, Bartish et al. (2006) examined chalcone synthase intron sequence polymorphism (Chsi) of 131 individuals. Altogether, 81 haplotypes were recorded. Their phylogenetic tree topology proved several deep splits between the Chsi haplotypes of $H$. rhamnoides from Europe/Asia Minor.

Since the Hungarian sea buckthorn population represents a valuable and prominent natural gene reserve of the species in East-Central Europe, the goal of our study was to characterize and estimate the genetic assessment of genotypes survived in the small edaphic sandy habitat of Ujpest, and to evaluate the remnant genetic material in comparison to planted specimens used in the horticultural practice and to reported European accessions using different molecular markers.

\section{Materials and Methods}

\section{Plant material}

The target native population of $H$. rhamnoides is situated in the Nature Reserve Area of Ujpest, in the outskirts of Budapest city, Hungary. The size of this protected population was estimated to be around 200 individuals grouping in five main clusters without any geographical isolation. As $H$. rhamnoides is able to develop large clones and has strong vegetative propagation ability by root suckers, we do not know the exact number of genets within the population and along the five clusters. However, we sampled leaf material equally from each cluster, altogether 68 specimens. To evaluate the genetic background of the native population, 12 cultivars preserved in the Soroksár experimental farm of the Szent István University were also involved in the study: 'Hergo', 'Leikora', 'Frugana'; 'Oranzsevaja', 'Jantarnaja', 'Obilnaja', 'Aromata', 'Avr', 'Petô 2', 'Római 2', 'S20' and 'Pollmix' (Table 1). On the roadside of the 2A Hungarian highway, at the vicinity of the Nature Reserve Area sea buckthorn shrubs were also planted. We sampled from this roadside hedge 8 genotypes to evaluate the genetic links to native individuals (Table 1).

\section{DNA extraction and PCR analyses}

DNA was extracted from the frozen leaves with DNeasy Plant Mini Kit (Qiagen, Hilden, Germany) following the procedures described by manufacturers.

A set of 7 SSR primer (Table 2) specific to Hippophae chromosomes were selected based on the polymorphic loci described previously (Wang et al., 2008; Jain et al., 2010).

PCR amplifications were performed in $25 \mu \mathrm{l}$ reaction mixture containing $25 \mathrm{ng}$ of DNA, 10 x PCR buffer (Fermentas-Thermo Scientific, Burlington, Canada), 2.5 $\mathrm{mM}$ dNTP, $0.4 \mu \mathrm{M}$ of the primers and 0.625 U Taq DNA polymerase. 
To detect the sequence polymorphism of Chsi, the $\mathrm{CHSx} 1 \mathrm{~F}$ and $\mathrm{CHS} \times 2 \mathrm{RN}$ universal primers were used (Strand et al., 1997). Following Korekar et al. (2012) HrXI and $H r X 2$ SCAR-markers were used to determine the rate of genders in the population. PCR amplifications were performed also in $25 \mu \mathrm{l}$ reaction mixture: $0.625 \mathrm{U}$ DreamTaq DNA polymerase $10 \times$ x DreamTaq buffer (Fermentas-Thermo Scientific, Burlington, Canada), 2.5 $\mathrm{mM} \mathrm{MgCl}, 10^{-2} \mathrm{mg} / \mathrm{ml} \mathrm{BSA}, 2.5 \mathrm{mM}$ dNTP, $0.4 \mu \mathrm{M}$ of the primers and 25 ng DNA. All reactions were carried out in PTC 200 (MJ Research, Quebec, Canada) using the program described for the primers.

The amplified PCR products were separated on $1 \%$ TAE agarose gels for $2 \mathrm{~h}$ at $60 \mathrm{~V}$ and DNA bands were stained with ethidium bromide. Fragment sizes were estimated by comparison with the $1 \mathrm{~kb}$ DNA ladder (Fermentas-Thermo Scientific, Burlington, Canada). For analysing fragment length polymorphism of the SSRs, the fluorescently labelled products were run in an automated sequencer ABI Prism 3100 Genetic Analyzer using the ABI Peak Scanner 1.0 (Applied Biosystems, Foster City, California, USA) and GS500 LIZ size standard (Applied Biosystems).

\section{DNA sequencing and sequence analysis}

Chsi PCR products were cloned to $\mathrm{pTz}-57 \mathrm{R} / \mathrm{T}$ (Fermentas) plasmid vector. The ligated plasmid vectors were transformed into DH5a competent Escherichia coli cells prepared with Z-CompetentTM E. coli
Transformation kit (Zymo Research Corp., Irvine, USA). Plasmid DNA was isolated with the EZ-10 Spin Column Plasmid DNA kit (Bio Basic Inc.) and sequenced in an automated sequencer ABI PRISM 3100 Genetic Analyzer (Applied Biosystems). For each fragment, the nucleotide sequences of two or three clones were determined in both directions with sequencing primer M13. DNA sequences were compared using BLASTN at NCBI and ClustalW program (Thompson et al., 1994), and the aligned sequences were edited with BioEdit v.7.0.9.0. A phylogenetic tree was generated using maximum parsimony method with MEGA version 4.0 (Kumar et al., 2004), including the three group of samples; the native specimens, the specimens from near the road and the planted garden cultivars. The sequences used for these analyses were: DQ109656; DQ109645; DQ109634; DQ109638; DQ109657, DQ109640; DQ109639; DQ109647; DQ109658; DQ109626; DQ109627; DQ109624; DQ109632; DQ109616; DQ109655; DQ109620; DQ109617; DQ109619; DQ1096660; DQ109663; DQ109593; DQ109597; DQ109598; DQ109594; DQ109592; DQ109620; DQ109599; DQ109633; DQ109660; DQ109651; KJ542877; KJ542879; KJ542878; KJ542871; DQ109607; DQ109582; DQ109652; DQ109600; DQ109601. NCBI accession numbers of isolated sequences of this study are: MK034737-MK034744. The 50\% majority-rule consensus of the most parsimonious trees was prepared for the phylogenetic analysis.

Table 1. The sampled specimens of Hippophae rhamnoides involved in the study

\begin{tabular}{|c|c|c|}
\hline Accession & Location of the five sampling clusters in Újpest Nature Reserve Area & $\begin{array}{c}\text { Number of specimens sampled from each } \\
\text { clusters }\end{array}$ \\
\hline & 1) $47^{\circ} 36^{\prime} 9.2658^{\prime \prime} ; 19^{\circ} 05^{\prime} 52.8138^{\prime \prime}$ & 34 \\
\hline & 2) $47^{\circ} 36^{\prime} 9.8022^{\prime \prime} ; 19^{\circ} 05^{\prime} 46.6332^{\prime \prime}$ & 6 \\
\hline Native population from the Újpest & 3) $47^{\circ} 36^{\prime} 9.918^{\prime \prime} ; 19^{\circ} 05^{\prime} 49.2216^{\prime \prime}$ & 5 \\
\hline \multirow[t]{3}{*}{ Nature Reserve } & 4) $47^{\circ} 36^{\prime} 8.8128^{\prime \prime} ; 19^{\circ} 05^{\prime} 46.6506^{\prime \prime}$ & 18 \\
\hline & 5) $47^{\circ} 366^{\prime} 6.5052^{\prime \prime} ; 19^{\circ} 05^{\prime} 52.7568^{\prime \prime}$ & 6 \\
\hline & all five clusters & 68 \\
\hline $\begin{array}{l}\text { Planted individuals from the } 2 \mathrm{~A} \text { roadside } \\
\qquad(\mathrm{Hu})\end{array}$ & $47^{\circ} 35^{\prime} 49.04^{\prime \prime} ; 19^{\circ} 08^{\prime} 25.49^{\prime \prime}$ & 8 \\
\hline $\begin{array}{l}\text { Cultivars from the Soroksár Gene Bank } \\
\qquad(\mathrm{Hu})\end{array}$ & $47^{\circ} 24^{\prime} 03.0^{\prime \prime} ; 19^{\circ} 09^{\prime} 12.5^{\prime \prime}$ & 12 \\
\hline
\end{tabular}

Table 2. List of SSR primer pairs used in the study

\begin{tabular}{cccc}
\hline Primer & Motif & Type & Reference \\
\hline HrMS003 & $(\mathrm{TCA}) 6$ & EST-SSR & Jain et al., 2010 \\
HrMS012 & $(\mathrm{CTT}) 11$ & EST-SSR & Jain et al., 2010 \\
HrMS025 & $(\mathrm{AG}) 8$ & EST-SSR & Jain et al., 2010 \\
Hr01 & $(\mathrm{GA}) 11$ & SSR & Wang et al., 2008 \\
Hr02 & $(\mathrm{AG}) 9$ & SSR & Wang et al., 2008 \\
Hr03 & $(\mathrm{AG}) 10$ & SSR & Wang et al., 2008 \\
Hr06 & $(\mathrm{CA}) 9$ & SSR & Wang et al., 2008 \\
\hline
\end{tabular}


5 in locus $\mathrm{Hr} 03$ ( 78 bp, 84 bp, 86 bp, 92 bp and 96 bp); 7 in locus $\mathrm{Hr} 06$ (71 bp, 73 bp, 75 bp, 85 bp, 87 bp, 91 bp and 93 bp); 5 in locus HrMS003 (250 bp, 324 bp, 338 bp, 340 bp and $354 \mathrm{bp}$ ), while 4 in locus HrMS12 (143 bp, 145 bp, 149 bp and $155 \mathrm{bp}$ ). These above listed genotypes were not detected in the native population of Ujpest. We found 6,66 alleles in average within the studied cultivars (Table 3 ).

\section{Length polymorphism of Chsi}

Since the size of $C h s i$ showed very remarkable variability in the genus Hippophae, we cloned and sequenced this region in two individuals $(35 / 2,42 / 3)$ with different SSRprofile from the native population of Újpest, one genotype (78/6) from the highway 2A, and 3 cultivars ('Jantarnaja', 'Frugana' and 'Pollmix'). Bartish et al. (2006) identified 81 haplotypes from the sequence information of 131 individuals originated from Europe and Asia Minor. The fragments length ranged from $628 \mathrm{bp}$ to $778 \mathrm{bp}$. Phylogenetic analysis revealed 7 lineages among the haplotypes, which were plotted on maps. We detected one or two alleles in our samples with different sizes: $691 \mathrm{bp}$ in $35 / 2,695$ bp in $42 / 3,714$ bp in 78/6, 593 and 719 bp in 'Frugana', $711 \mathrm{bp}$ in 'Jantarnaja', while $650 \mathrm{bp}$ and $627 \mathrm{bp}$ in the male cultivar. After BLAST homology, a majorityrule consensus tree of maximum likelihood analysis was carried out with other 39 downloaded Hippophae Chsi sequences (Fig. 1). Samples from Ujpest belonged to the II. lineage, which is distributed mostly in Western and MiddleEurope, and Romania. 'Pollmix' and the genotype from route $2 \mathrm{~A}$ belonged to the lineage I (bootstrap value $>50 \%$ ). The 'Frugana' German cultivar was placed in group IV, representing the German and Eastern Carpathian lineage detected by Bartish et al. (2006).

\section{Rate of genders}

Determining the rate of genders is crucial from the perspective of the population's survival at dioecious plants. In the nature reserve, the sea buckthorn individuals without fruit were not considered male. Distinction of the two genders is almost impossible based on morphological markers (Kalia et al., 2011). Korekar et al. (2012) designed two SCAR markers $(\mathrm{HrX} 1, \mathrm{HrX}$ ) allowing to determine individual gender. The same SCAR markers were tested by Chawla et al. (2014) in H. rhamnoides, H. tibetana and $H$. salicifolia. Both SCAR markers $(\mathrm{HrXl}, \mathrm{HrX2})$ used produced optimal amplification in $H$. rhamnoides, but only $\mathrm{HrXl}$ amplified fragments in $H$. tibetana and $H$. salicifolia.

The female specific $\mathrm{Hr} X 2$ marker revealed fragments (386 bp) in 34 from 76 samples (Fig. 2). Altogether 28 samples from Újpest were scored female, which means the female ratio to the male is $1: 1.42$. Based on our results, $\mathrm{HrX} 2$ is a reliable tool to determine genders. in locus Hr02 (151 bp, $157 \mathrm{bp}, 159 \mathrm{bp}, 165 \mathrm{bp}$ and $169 \mathrm{bp}$ );

Table 3. Number of SSR alleles for the three type of dataset

\begin{tabular}{|c|c|c|c|c|c|c|c|c|c|c|}
\hline \multirow{3}{*}{ Samples } & & & & & & & \multirow{3}{*}{ All loci } & \multirow{3}{*}{$\mathrm{Na}$} & \multirow{3}{*}{$\mathrm{Ne}$} & \multirow{3}{*}{ I } \\
\hline & HR01 & $\mathrm{Hr} 02$ & $\mathrm{Hr} 03$ & $\mathrm{Hr} 06$ & HrMS003 & HrMS012 & & & & \\
\hline & \multicolumn{6}{|c|}{ No. alleles } & & & & \\
\hline Native populations (68 indiv.) & 3 & 3 & 5 & 2 & 2 & 2 & 17 & 2.833 & 2.343 & 0.8 \\
\hline Planted (8 indiv.) & 4 & 4 & 5 & 7 & 5 & 4 & 29 & 4.833 & 3.683 & 1.4 \\
\hline Cultivars (12) & 7 & 7 & 6 & 4 & 8 & 7 & 40 & 6.833 & $4.4^{*}$ & $1.62^{*}$ \\
\hline
\end{tabular}

Na: number of alleles; Ne: number of effective alleles; I: Shannon diversity index; ${ }^{*}$ Because of different bred specimens diversity indices have only informative value 


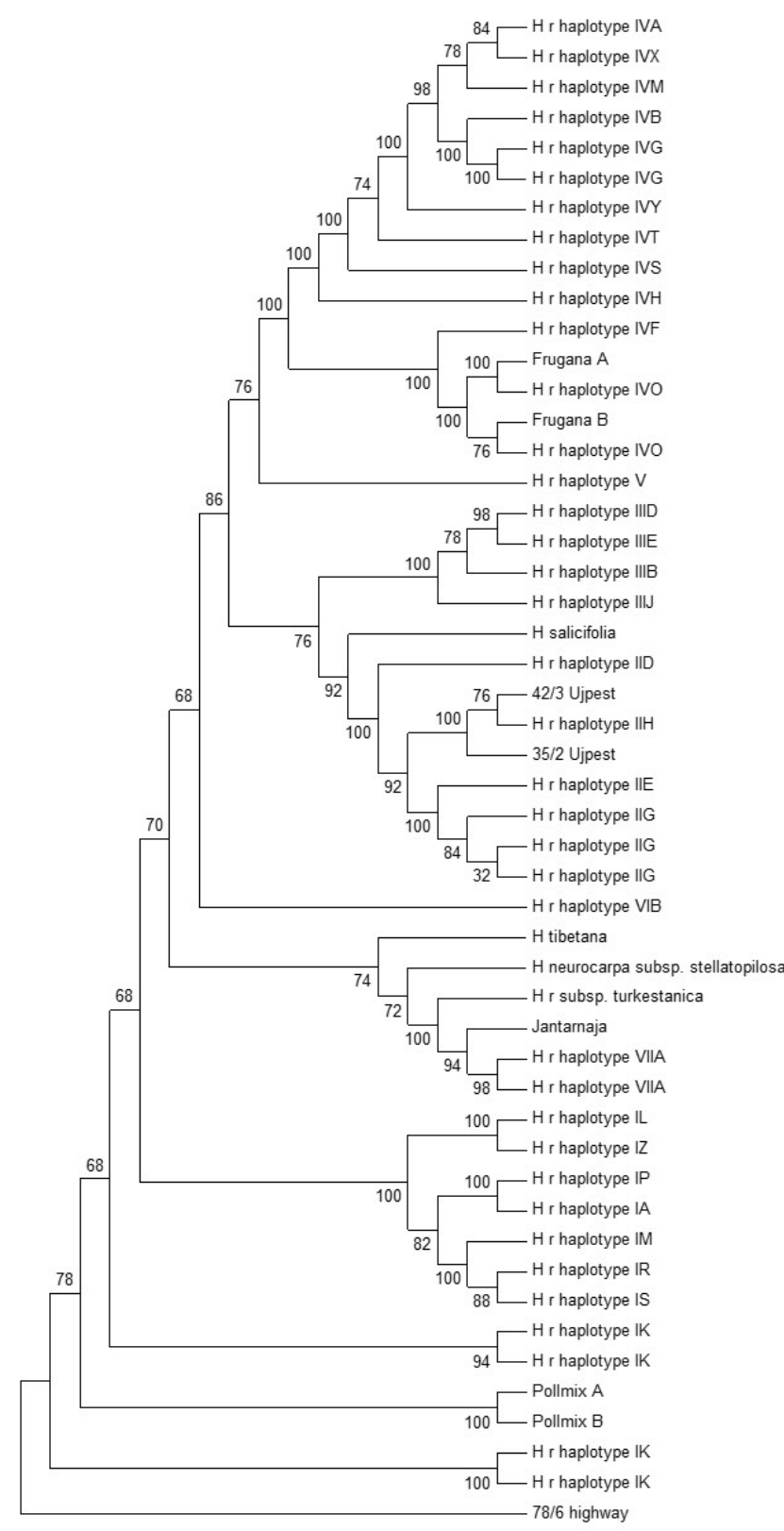

Fig. 1. A phylogenetic tree was generated using the maximum parsimony method on Chsi haplotype sequences of Hippophae rhamnoides, based on multiple alignments, with bootstrap analysis with 1000 replications (MEGA software version 4.0, Kumar et al., 2004). Bootstrap values are indicated on the branches. H.r. haplotype sequences were downloaded from $\mathrm{NCBI}$, new sequences isolated in this study signed as: Frugana $\mathrm{A}$ and B, 42/3 Ujpest, 35/2 Ujpest, Jantarnaja, Pollmix A and B

\section{Discussion}

Based on SSR loci published by Wang et al. (2008) for Hippophae rhamnoides subsp. sinensis, and Jain et al. (2010) who have designed EST-SSR primers based on $H$. rhamnoides, $H$. salicifolia and $H$. tibetana we selected six SSR markers that proved to be polymorphic in our study in

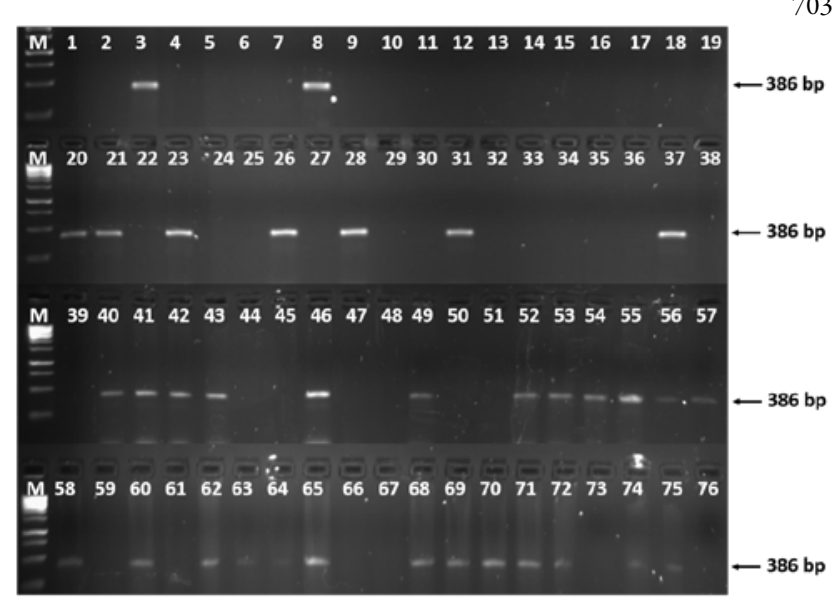

Fig. 2. Amplification profile of the SCAR marker $\mathrm{HrX} 2$, showing the $386 \mathrm{bp}$ fragment in female genotypes (Korekar et al., 2012). M. 1 kb Gene Ruler DNA ladder (Thermo Fisher Scientific); 1-68 genotypes from Hungarian sea buckthorn population; 69-72 female control cultivars: 'Hergo', 'Leikora', 'Frugana'; 'Oranzsevaja', 73 male control cultivar 'Pollmix', 7476 genotypes from $2 \mathrm{~A}$ Hungarian highway

the three groups of sampled specimens: (i) selected cultivars from Soroksár experimental farm; (ii) planted individuals of unknown origin from the vicinity of the $2 \mathrm{~A}$ highway; (iii) putative genets from the native population of Ujpest Nature Reserve. Our microsatellite analysis pointed out the extremely low variation of the native sea buckthorn population from the Hungarian Ujpest Nature Reserve area compared to the two other groups. The stand is homogeneous with a decreased number of alleles compared to the studied cultivars as well the involved planted individuals from near the highway. From the six SSR markers that could have been evaluated 68 individuals from the native population presented 2 or 3 alleles/locus and in one locus 5 alleles while the six garden cultivars and eight planted specimens presented 4 to 9 and 4 to 7 alleles/locus.

Genetic background of the native population indicates that the primary spreading mechanism of plants is mainly clonal, by root suckers. Only very few seedlings were found. Due to the degradation of the habitat and increasing environmental stress - like the highway in the vicinity or the bridge across the Danube, construction of electricity poles, trash, appearance of non-native species, increased air pollution - most probably only some individuals could survive and only the most resistant genotypes have been preserved. Borzan and Schlarbaum (1997), has found growing sterility among the pollen due to air pollution in case of Pinus sylvestris, Picea spp., Quercus spp. Moreover, low genetic variability and harmful environmental conditions (reduced fertilization) can lead to inbreeding depression (Mátyás, 2002). The low genetic variability is especially dangerous in case of an isolated population like in this case. In a genetically unstable population the defence system of the plants is vulnerable; an infection could be dangerous for the whole group. Reduced genetic diversity decrease the evolutionary potential of species to adapt to changing environments (Leimu et al., 2006). In Újpest area 
704

it was almost impossible to separate the individuals from each other, the groups in the population consisted of a few, clonal plants. From the aspect of nature conservation, this has high significance since some population may seem bigger than they actually are (Lendvay et al., 2013).

In the nature reserve area, we found female plants in three of the five groups of plants. The gender rate calculated for the native population differs from the result by Huxley (1992), where the sex ratio in favour of the females was 0.6. According to Li et al. (2007) under bad conditions this ratio is in favour of males and it is roughly balanced under appropriate environment. While the male individuals use their energy for vegetative growth, the female plants spread rather sexual (Massei et al., 2006). In case of Hippophae - as a wind-pollinated species - the male plants are more common among the seedlings (De Jong and Mejiden, 2004). Hippophae cannot tolerate even its own shading which interferes with the growth of the seedlings. Gadó and Karcza (1999) mentioned the same groups of individuals in the Újpest population as we have observed. According to their analysis the rate of genders was found more offset in males, as it is now. The improvement could be caused by the rehabilitation done recently in the area by reducing the biomass of the shading vegetation.

DNA sequence variation at an intron from a nuclear gene encoding the chalcone synthase enzyme (CHS; EC 2.3.1.74) offers useful technique to evaluate the polymorphism or to reveal phylogeographical aspects (Strand et al., 1997). A consensus tree of maximum likelihood analysis showed clear separation of the native Újpest population from the planted individuals in the vicinity. Latter proved to be of allochtonous origin clustering with the Russian samples. Although these planted individuals of higher genetic variation are at small distance from the native population (not more than few $\mathrm{km}$ ), sequence variation, as well as lack of common SSR fragments provided evidence for genetic isolation between the two stands. The native population with its two alleles falls within the group of the Western- and CentralEuropean samples including Romania, region which has strong links to the Balkan and the Black Sea area from where according to Bartish et al. (2006) expansion of sea buckthorn populations started in the last cooling period of the Pleistocene colonizing Europe and Scandinavia. The population's withdrawal has been presumed to have happened during the warming period of the Holocene as result of the competitive exclusion by the spread of warm adapted broadleaf species. Sea buckthorn could survive in specific edaphic habitats like the pioneer row sandy substrates near the rivers (Bartish et al., 2006). The genetic material of low variation was sustained by clonal structure fixing presumably the most adapted genotypes. Although in case of our population we have not detected population specific genotypes, the low SSR variation compared to the cultivated specimens, and the reproductive isolation (ie. lack of common alleles) of the population, give strong support for the relict status of this small population from the remnant habitat of Újpest area. Based on our study we suggest ex situ conservation and intensive nature protection measures to maintain one of the last native sea buckthorn populations of the Pannonian region.

\section{Conclusions}

Genetic assessment of the native Hungarian sea buckthorn population indicates a different and highly pauperised gene stock compared to the cultivated specimens as well as planted individuals. The strong clonal population structure reflects long term survival and mostly vegetative propagation ability and isolation. The preserved gene stock with the genetically different allele composition is one of the last that derives most probably from an ancient lineage spreading from the Balkan towards Central Europe.

\section{Acknowledgements}

This research was supported by the Higher Education Institutional Excellence Program (1783-3/2018/ FEKUTSTRAT) awarded by the Ministry of Human Capacities within the framework of plant breeding and plant protection researches of Szent István University.

\section{References}

Bartish IV, Jeppsson N, Bartish GI, Lu R, Nybom H (2000). Inter- and intraspecific genetic variation in Hippophae (Elaeagnaceae) investigated by RAPD markers. Plant Systematics and Evolution 225:85-101.

Bartish IV, Jeppsson N, Nybom H (1999). Population genetic structure in the dioecious pioneer plant species Hippophae rhamnoides investigated by random amplified polymorphic DNA (RAPD) markers. Molecular Ecology 8:791-802.

Bartish IV, Jeppsson N, Nybom H, Swenson U (2002). Phylogeny of Hippophae (Elaeagnaceae) inferred from parsimony analysis of chloroplast DNA and morphology. Systematic Botany 27:41-54.

Bartish IV, Kadereit JW, Comes HP (2006). Late quaternary history of Hippophae rhamnoides L. (Eleagnaceae) inferred from chalcone synthasw intron (Chsi) sequences and chloroplast DNA variation. Molecular Ecology 15:4065-4083.

Bawa AS, Khanum F, Singh B (2002). Seabuckthorn a wonder plant. Natural Products Radiance 1(4):8-14.

Borzan Z, Schlarbaum SE (1997). Cytogenetic studies of forest trees and shrub species. Proceedings of the First IUFRO Cytogenetics Working Party S2.04-08 Symposium, September 8-11, 1993, Brijuni National Park, Croatia. HrvatskeŚume.

Chawla A, Kant A, Stobdan T, Srivastava RB, Chauhan RS (2014). Crossspecies application of sex linked markers in $H$. salicifolia and $H$. tibetana. Scientia Horticulturae 17:281-283.

De Jong TJ, Van der Meijden E (2004). Sex ratio of some long-lived dioecious plants in a sand dune area. Plant Biology 6(5):616-620.

Enkhtaivan G, John KM, Pandurangan M, Hur JH, Leutou AS, Kim DH (2017). Extreme effects of sea buckthorn extracts on influenza viruses and human cancer cells and correlation between flavonol gycosides and biological activities of extracts. Saudi Journal of Biological Sciences 24(7):1646-1656.

Gadó GyP, Kerényi-Nagy V (2012). Közönséges homoktövis [Hippophae rhamnoides]. In: Bartha D (Eds). Magyarország ritka fa- és cserjefajainak atlasza [Atlas of rare shrubs and trees in Hungary]. Kossuth Kiadó, Budapest pp 236-240. 
Gadó Gy, Karcza Zs (1999). Veszélyeztett fajok Magyarországon. WWF Magyarország, Budapest.

Huxley A (1992). Green inheritance: the World Wildlife Fund book of plants. Four Walls Eight Windows. New York, USA.

Jain A, Ghandal R, Grover A, Raghuvanshi S, Prakash CS, Sharma PC (2010). Development of EST-based new SSR markers in seabuckthorn Physiology and Molecular Biology of Plants 160(4):375-378.

Jia DR, Abbott RJ, Liu TL, Mao KS, Bartish IV, Liu JQ (2012). Out of the Quinghai-Tibet Plateau: evindence for the origin and dispersal of Eurasian temperate plants from a phylogeographic study of Hippophae rhamnoides (Elaeagnaceae). New Phytologist 194:1123-1133.

Kalia RK, Singh R, Rai MK, Mishra GP, Singh SR, Dhawan AK (2011). Biotechnological interventions in sea buckthorn (Hippophae L.): current status and future prospects. Trees 25(4):559-575.

Korekar G, Sharma RK, Kumar R, Meenu Bisht NC, Srivastava RB, Ahuja PS, Stobdan T (2012). Identification and validation ofsex-linked SCAR markers in dioecious Hippophae rhamnoides L. (Elaeagnaceae). Biotechnology Letters 34:973-978.

Kumar S, Nei M, Dudley J (2004). MEGA4: Molecular evolutionary genetics analysis (MEGA) software version 4.0. Molecular Biology and Evolution 24:1596-1599.

Lacis G, Kota-Dombrovska I (2014). Assessment of genetic diversity of Latvian sea buckthorn (Hippophae rhamnoides L.) germplasm using molecular markers. Zemdirbyste-Agriculture 101(3):333-340.

Leimu R, Mutikainen PIA, Koricheva J, Fischer M (2006). How general are positive relationships between plant population size, fitness and genetic variation? Journal of Ecology 94(5):942-952.

Lendvay B, Pedryc A, Höhn M (2013). Characterization of nuclear microsatellite markers for the narrow endemic Syringa josikaea Jacq. fil. ex Rchb. Notulae Botanicae Horti Agrobotanici Cluj-Napoca 41:301305.

Li C, Xu G, Zang R, Korpelainen H, Berninger F (2007). Sex-related differences in leaf morphological and physiological responses in Hippophae rhamnoides along an altitudinal gradient. Tree Physiology 27:399406.

Li H, Ruan CJ, Teixeira da Silva JA (2009). Identification and genetic relationship based on ISSR analysis in a germplasm collection of sea buckthorn (Hippophae L.) from China and other countries. Scientia Horticulturae 123:263-271.

Li TS, Schroeder WR (1996). Sea buckthorn (Hippophae rhamnoides L.): A multipurpose plant. Hort Techology 6(4):370-380.

Lian YS, Chen XI, Lian H (1998). Systematic classification of the genus Hippophae L. Seabuckthorn Research 1:3-23.

Mangla Y, Chaudhary M, Gupta H, Thakur R, Goel, S, Raina SN, Tandon $\mathrm{R}$ (2015). Facultative apomixis and development of fruit in a deciduous shrub with medicinal and nutritional uses. AoB Plants 7:plv098.
Massei G, Watkins R, Hartley SE (2006). Sex-related growth and secondary compounds in Juniperus oxycedrus macrocarpa. Acta Oecologica 29:135140.

Mátyás Cs (2002). A környezetet terhelö antropogén hatások lehetséges genetikai következményei. In: Mátyás C (Eds.). Erdészetitermészetvédelmigenetika. Mezőgazda Kiadó, Budapest pp 255-260.

Raina SN, Jain S, Sehgal D, Kumar A, Dar TH, Bhat V, Rani V (2012). Diversity and relationships of multipurpose seabuckthorn (Hippophae L.) germplasm from the Indian Himalayas as assessed by AFLP and SAMPL markers. Genetic Resources and Crop Evolution 59(6):10331053.

Rousi A (1965). Observation on the cytology and variation of European and Asiatic populations of Hippophae rhamnoides. Annales Botanici Fennici 2:1-18.

Sezen I, Ercisli S, Cakir O, Koc A, Temim E, Hadziabulic A (2015). Biodiversity and landscape use of sea buckthorn (Hippophae rhamnoides L.) in the Coruh valley of Turkey. Erwerbs-Obstbau 57(1):23-28.

Sheng HM, An LZ, Chen T, Xu SJ, Lu GX, Zheng XL, Pu LL, Lu YJ, Lian YS (2006). Analysis of genetic diversity and relationships among and within species of Hippophae (Elaeagnaceae) based on RAPD markers. Plant Systematics andEvolution 260:25-37.

Srihari JM, Verma B, Kumar N, Chahota RK, Singh V, Rathour R, Sharma TR (2013). Analysis of molecular genetic diversity and population structure in sea buckthorn (Hippophae spp L.) from north-western Himalayan region of India. Journal of Medicinal Plants Research, 7(43):3183-3196.

Strand AE, Leebens-Mack J, Milligan BG (1997). Nuclear DNA-based markers for plant evolutionary biology. Molecular Ecology 6:113-118.

Sun K, Chen X, Ma R, Li C, Wang Q, Ge S (2002). Molecular phylogenetics of Hippophae L. (Elaeagnaceae) based on the internal transcribed spacer (ITS) sequences of nrDNA. Plant Systematics and Evolution 235:121-134.

Swenson U, Bartish IV (2003). Taxonomic synopsis of Hippophat (Elaeagnaceae). Nordic Journal of Botany 22:369-374.

Thompson JD, Higgins DG, Gibson TJ (1994). CLUSTAL W: improving the sensitivity of progressive multiple sequence alignment through sequence weighting, position-specific gap penalties and weight matrix choice. Nucleic Acids Resources 22(22):4673-4680.

Tian C,Lei Y, Shi S, Nan P, Chen J,Zhong Y (2004). Genetic diversity of sea buckthorn (Hippophae rhamnoides) populations in northeastern and northwestern China as revealed by ISSR markers. New Forests 27(3):229-237.

Wang A,ZhangQ, Wan D, Liu J (2008). Nine microsatellite DNA primers for Hippophae rhamnoides ssp. sinensis (Elaeagnaceae). Conservation Genetics 9:969-971. 